\title{
Hereditary renal cell carcinoma associated with von Hippel-Lindau disease: a description of a Nova Scotia cohort
}

\author{
Shannon Bradley, MD; ${ }^{*}$ Nadine Dumas, MSc; ${ }^{\dagger}$ Mark Ludman, MD; ${ }^{\prime \neq}$ Lori Wood, MD, MSc ${ }^{*}$
}

\begin{abstract}
Background: von Hippel-Lindau (VHL) disease is an autosomal dominant condition characterized by the development of benign and malignant tumours, including cases of renal cell carcinoma (RCC). Early detection of RCC through routine surveillance can lead to decreased morbidity and mortality. Data on the number of patients in Nova Scotia (NS) who have VHL disease, disease manifestations and the frequency and mode of the surveillance have not previously been collected or reported. This project was designed to obtain that information.
\end{abstract}

Methods: The number and management of patients with VHL disease was determined by multiple sources: the Maritime Medical Genetics Service, patient charts, and pathology, radiology and laboratory data. The actual surveillance being performed was compared with that recommended in the literature.

Results: Twenty-one patients from 11 families in NS were identified. Manifestations included cases of RCC (31.6\%), central nervous system (CNS) hemangioblastoma (73.7\%), retinal hemangioma $(47.4 \%)$, renal cyst $(47.4 \%)$ and pheochromocytoma (10.5\%). Of the 6 patients with RCC, 4 had bilateral tumours, 2 required kidney transplants and 1 developed metastatic disease. Routine surveillance was being done for the CNS in $62.5 \%$ of patients, retina in $47.4 \%$, abdomen in $43.8 \%$ and urine catecholamines in only $10.5 \%$. Only 1 of the 6 patients who developed RCC was undergoing routine abdominal imaging. Surveillance investigations were ordered by a number of different specialists.

Conclusion: Patients with VHL disease in NS have a number of manifestations associated with their disease, including RCC, in a similar frequency to that reported in the literature. The surveillance of these patients is suboptimal in frequency and coordination. von Hippel-Lindau disease is a complex condition that requires a coordinated approach to care to ensure proper surveillance and treatment. Our study highlights current deficiencies and offers an enormous opportunity for improvement.

Can Urol Assoc J 2009;3(1):32-6

\section{Résumé}

Généralités : La maladie de von Hippel-Lindau (VHL) est une maladie à transmission autosomique dominante caractérisée par la formation de tumeurs bénignes et malignes, dont l'hypernéphrome. Le dépistage précoce de l'hypernéphrome par des examens réguliers peut amener une réduction de la morbidité et de la mortalité. On ne sait pas combien de personnes sont atteintes de VHL en Nouvelle-Écosse, quelles sont les manifestations de la maladie chez ces patients et quels tests de dépistage sont effectués et à quelle fréquence. Le projet décrit ici visait à obtenir ces renseignements. Méthodologie : Le nombre et la méthode de prise en charge des patients atteints de VHL ont été établis à l'aide de plusieurs sources : la Clinique de génétique médicale des Maritimes, des dossiers de patients, des rapports de pathologie et de radiologie et des analyses de laboratoire. Les méthodes de surveillance mises en place ont été comparées aux méthodes recommandées dans la littérature médicale.

Résultats : Vingt et un patients de 11 familles de Nouvelle-Écosse ont été cernés. Les manifestations incluaient : hypernéphrome (31,6 \%), hémangioblastomes siégeant au niveau du SNC (73,7\%), hémangiomes rétiniens $(47,4 \%)$, kystes rénaux $(47,4 \%)$ et phéochromocytomes (10,5\%). Sur les six patients porteurs d'un hypernéphrome, 4 avaient des tumeurs bilatérales, 2 ont eu besoin $\mathrm{d}^{\prime}$ une transplantation rénale et un patient a présenté des métastases. De tous les patients atteints de VHL, 62,5\% ont subi des tests réguliers de dépistage au niveau du SNC, 47,4\%, au niveau de la rétine, 43,8 \%, au niveau de l'abdomen, et seulement 10,5\% des patients ont subi des tests réguliers de dépistage des catécholamines urinaires. Sur les 6 cas d'hypernéphrome, un seulement subissait des épreuves régulières d'imagerie au niveau de l'abdomen. Les tests de dépistage avaient été prescrits par différents spécialistes.

Conclusion : Les cas de VHL en Nouvelle-Écosse présentent un certain nombre de manifestations liées à cette maladie, dont l'hypernéphrome, à une fréquence proche de celle mentionnée dans la littérature. La fréquence et la coordination des épreuves de dépistage sont sous-optimales. La maladie de VHL est une affection complexe nécessitant une bonne coordination des soins afin d'assurer une surveillance et un traitement adéquats. Cette étude montre les lacunes actuelles et pointe vers des améliorations substantielles.

\section{Background}

Renal cell carcinoma (RCC) comprises 95\% of kidney cancers and is estimated to be the ninth most common cancer diagnosed in Canada in 2008. In Canada, the incidence of RCC is rising and an estimated 4400 new cases will be diagnosed in 2008 and 1600 deaths will result. ${ }^{1}$ 
Most cases of RCC occur sporadically; however, $5 \%$ have a hereditary basis. The most common and well-studied form of hereditary RCC is that associated with von Hippel-Lindau (VHL) disease. It is an autosomal dominant condition characterized by the formation of both benign and malignant tumours, including cases of cerebellar, spinal, brainstem and retinal hemangioblastoma, RCC, renal cyst, pheochromocytoma, pancreatic cyst, broad ligament and epididymal cyst and endolymphatic sac tumour. ${ }^{2}$ Up to $45 \%$ of all people diagnosed with VHL disease will develop RCC. Those who develop RCC have a shortened life expectancy, and RCC is the leading cause of death in patients with VHL disease. ${ }^{2}$ In these patients, RCC tends to occur at a young age, and is often multiple and bilateral. ${ }^{3}$ Detection of small tumours, early in the disease course, offers a better chance of organ preservation as well as cure. Surveillance programs for not only RCC, but also the other manifestations of VHL disease, have been recommended to detect abnormalities early and influence the course of disease.

The goal of our study was to determine how many patients in Nova Scotia (NS) had VHL disease and how they were being cared for. Our specific objectives included the following: documenting how many patients in NS had VHL disease, the pattern of tumour development, the frequency and mode of surveillance, and which specialists were involved in the care with a focus on RCC. We planned to compare the actual surveillance being performed in NS with published surveillance protocols.

\section{Methods}

Research ethics board approval for this project was obtained. To establish how many patients in NS had been diagnosed with VHL disease, we used several sources, including the following: a list of all patients who had genetic testing for VHL disease by the IWK Molecular Diagnostic Laboratory in Halifax, a list of patients who had genetic counselling regarding VHL disease at the Maritime Medical Genetics Service in Halifax, pedigree analysis from the Maritime Medical Genetics Service charts, pathology reports coded for cases of central nervous system (CNS) hemangioblastoma, and individual specialists in neurosurgery, neurology, ophthalmology, urology and internal medicine were asked to provide the names of patients with known $\mathrm{VHL}$ disease under their care.

From these sources, a review of patients' hospital charts, radiology reports and laboratory reports was conducted. Information including the date and method of diagnosis, VHL disease gene mutation, pattern of tumour development, frequency and modality of imaging, and treatment, along with the frequency and type of follow-up was obtained. Patients were not contacted directly.

Published guidelines for the surveillance of patients with VHL disease were obtained from the literature ${ }^{4-6}$ and from recommendations by the Newfoundland VHL Care Group, 7 Massachusetts General Hospital ${ }^{8}$ and the VHL Family Alliance. ${ }^{9}$ These guidelines vary slightly but the general concept of regular retinal examinations, urine catecholamine testing, as well as abdominal and CNS imaging was consistent. For the purposes of our study, the recommendations from these 6 available guidelines were coalesced and are summarized in Table 1. Compliance to surveillance with each screening modality was defined as having the recommended screening test at least $75 \%$ of the time.

\section{Results}

\section{Demographics}

Twenty-one patients with VHL disease from 11 families in NS were identified. Two patients were excluded from further analysis: there was no data available for 1 pediatric patient except for

\begin{tabular}{|c|c|}
\hline Infants and children $<11 \mathrm{yr}$ & Adults and children $>11 \mathrm{yr}$ \\
\hline $\begin{array}{l}\text { - Annual retinal examination } \\
\text { (every } 6 \text { mo if lesions) } \\
\text { - Annual urine catecholamine } \\
\text { testing }\end{array}$ & $\begin{array}{l}\text { - Annual retinal examination } \\
\text { (every } 6 \text { mo if lesions) } \\
\text { - Annual urine catecholamine } \\
\text { testing } \\
\text { - Annual abdominal imaging } \\
\text { (US/CT) } \\
\text { - Annual brain/spine imaging } \\
\text { (CT/MRI) }\end{array}$ \\
\hline \multicolumn{2}{|c|}{$\begin{array}{l}\mathrm{CT}=\text { computed tomography; MRI = magnetic resonance imaging; US = } \\
\text { ultrasonography. } \\
\text { *Two surveillance protocols recommend biannual central nervous system (CNS) } \\
\text { imaging, }{ }^{4,9} \text { and } 2 \text { recommend baseline CNS imaging at the time of diagnosis and only } \\
\text { again when symptoms arise. }{ }^{5,7}\end{array}$} \\
\hline
\end{tabular}


his genetic diagnosis, and 1 patient moved out of province 1 year after diagnosis and follow-up data was not available. The mean age at diagnosis was $22.4(0-48)$ years. Seventy-nine percent of patients were diagnosed with VHL disease on the basis of their clinical signs and the remaining patients were diagnosed based on genetic testing after a positive family history was identified. The clinical manifestations and age at first presentation are presented in Table 2 along with a comparison to data from the published literature.

\section{Genetic abnormalities}

Sixteen patients diagnosed with VHL disease had

\begin{tabular}{|c|c|c|c|c|}
\hline \multirow{3}{*}{$\begin{array}{l}\text { Manifestation } \\
\text { Cerebellar } \\
\text { hemangioblastoma }\end{array}$} & \multicolumn{2}{|c|}{$\%$ of patients } & \multirow{2}{*}{\multicolumn{2}{|c|}{$\begin{array}{c}\text { Mean age of } \\
\text { NS patients at } \\
\text { first diagnosis } \\
\text { yr (range) }\end{array}$}} \\
\hline & \multirow{2}{*}{$\begin{array}{r}\text { NS } \\
68.4\end{array}$} & \multirow{2}{*}{$\begin{array}{c}\text { Literature } \\
44-72\end{array}$} & & \\
\hline & & & 32.0 & $(10-46)$ \\
\hline $\begin{array}{l}\text { Spinal } \\
\text { hemangioblastoma }\end{array}$ & 31.6 & $13-50$ & 26.0 & $(16-48)$ \\
\hline $\begin{array}{l}\text { Brainstem } \\
\text { hemangioblastoma }\end{array}$ & 5.2 & $10-25$ & 16.0 & - \\
\hline Retinal angioma & 47.4 & $25-60$ & 29.0 & $(11-36)$ \\
\hline Renal cell carcinoma & 31.6 & $17-45$ & 34.0 & $(22-41)$ \\
\hline Renal cyst & 47.4 & $50-70$ & 31.5 & $(22-50)$ \\
\hline Pheochromocytoma & 10.5 & $0-19$ & 33.5 & (33-34) \\
\hline ELST & 0.0 & 11 & & \\
\hline Pancreatic cyst & 21.0 & $14-70$ & 40.0 & $(19-56)$ \\
\hline $\begin{array}{l}\text { Broad ligament/ } \\
\text { epididymis cysts }\end{array}$ & 5.2 & $17-54$ & 33.0 & - \\
\hline
\end{tabular}

Table 3. Overall compliance with screening modality ( $\%$ of patients undergoing recommended screening at least $75 \%$ of the time)

\begin{tabular}{lcc}
\hline Screening test & $\begin{array}{c}\text { RCC patients, } \\
n=6\end{array}$ & $\begin{array}{c}\text { All patients, } \\
n=19\end{array}$ \\
\hline Brain CT/MRI & 33.3 & 62.5 \\
Spine CT/MRI & 33.3 & 62.5 \\
Retinal examination & 16.7 & 47.4 \\
Abdominal US/CT & 16.7 & 43.5 \\
Urine catecholamine & 0.0 & 10.5 \\
CT = computed tomography, MRI = magnetic resonance imaging, RCC = renal cell \\
carcinoma, US = ultrasonography.
\end{tabular}

genetic testing. The most common mutation identified in the VHL disease gene was the point mutation A544G found in 9 patients. Another 2 patients had the point mutation A446G and 3 patients were found to carry a deletion. Two other patients had negative genetic testing; however, they were still felt to have $\mathrm{VHL}$ disease, on clinical grounds. Among patients with RCC, the A544G mutation, A446G mutation and a deletion were all identified.

\section{Renal cell carcinoma}

Six (31.6\%) VHL disease patients had been diagnosed with RCC. The mean age at diagnosis was 34 years with a range of 22-41 years. All tumours had clear cell pathology. Four patients had bilateral tumours and 2 of these patients underwent bilateral nephrectomies and subsequent renal transplant surgery. Three patients underwent nephron-sparing surgery with no subsequent recurrence of disease. One patient underwent a radiofrequency ablation procedure at the National Institute of Health. The only patient to have died in this series had metastatic RCC.

\section{Surveillance}

Screening interventions included computed tomography $(\mathrm{CT})$ or magnetic resonance imaging (MRI) of the brain and spinal cord, abdominal ultrasonography or $\mathrm{CT}$, retinal examination and measurement of urine catecholamines (Table 3). Compliance was highest with neuroimaging of the brain and spinal cord by CT or MRI and lowest with measurement of urine catecholamines. Of the patients who developed RCC, only 1 was undergoing routine abdominal imaging.

\section{Care providers}

A number of types of specialists were involved in the care of VHL disease patients in NS (Table 4). Patients were followed up by specialists in ophthalmology, neurology, neurosurgery, urology, medical genetics, internal medicine and pediatrics. The majority of patients had been seen by a medical geneticist, ophthalmologist and neurosurgeon at least once. There was no one physician or team responsible for ordering and following up on the various surveillance modalities. 


\section{Discussion}

Over the past 10 to 15 years, there has been an explosion of information regarding the VHL disease gene and its importance in VHL disease as well as sporadic RCC. ${ }^{11,12} \mathrm{VHL}$ disease gene mutations are found in $60 \%-85 \%$ of sporadic RCC. ${ }^{13}$ A normal function of the VHL disease gene includes the regulation of hypoxia-inducible genes. The normal VHL disease protein forms a complex with hypoxia inducible factor $1 \alpha$ $(\mathrm{HIF} 1 \alpha)$ and targets it for ubiquitinylation and degradation. When VHL disease is mutated, the abnormal gene product is unable to bind $\operatorname{HIF} 1 \alpha$, which leads to its accumulation and downstream transcription of many factors involved in angiogenesis and cell growth including vascular endothelial growth factor, platelet-derived growth factor, transforming growth factor- $\alpha$ and transforming growth factor- $\beta .^{12,14-16}$ Novel targeted therapies have been developed to exploit the $\mathrm{VHL}$ disease mutation and its downstream events in the treatment of advanced RCC.

Most cases of VHL disease result when a person inherits a mutated germline copy of the $\mathrm{VHL}$ disease gene from an affected parent and then, the remaining normal copy of the gene is inactivated by an event at the somatic level. Twenty percent of patients develop VHL disease as a result of a de novo mutation. More than 300 different VHL disease mutations have been identified with most being point mutations, but partial and complete gene deletions can occur. ${ }^{15}$ Some correlation between genotype and phenotype exists but is complex and incompletely understood. Variable expressivity is known in VHL disease as patients with identical VHL disease mutations can have very different clinical manifestations.

Our study found that 21 people from 11 families in NS had known VHL disease. This number is probably an underestimate of the true incidence and prevalence of $\mathrm{VHL}$ disease in NS, which is probably the most important limitation of this retrospective study. In fact, having reviewed the family pedigrees of these patients, there were many other family members who had not had genetic testing/counselling or any surveillance tests for $\mathrm{VHL}$ disease yet were known to be at high risk and may potentially have had undiagnosed VHL disease. This emphasizes the point, however, that these patients are not diagnosed or managed in a coor- dinated fashion in the current health care system.

Despite recent advances in the molecular genetics and pathophysiology of VHL disease as well as developing targeted therapy for RCC, the foundation to the management of patients with VHL disease continues to be early detection through genetic screening and regular clinical surveillance of both patients with VHL disease and their families. Increased sensitivity of imaging techniques and advances such as radiofrequency ablation and nephron-sparing surgery are allowing discovery and management of tumours at earlier stages, thereby decreasing the morbidity and mortality associated with VHL disease. ${ }^{4,10,17,18}$

For the 19 patients with VHL disease surveyed in NS, the clinical manifestations are much the same as that published in the literature. The adherence to a standard surveillance protocol, however, is less than optimal, with only $63 \%$ of patients having regular brain and spine imaging, $47 \%$ having retinal examinations, $44 \%$ having abdominal imaging and $11 \%$ having urine catecholamines. Only 1 of the 6 patients who developed RCC was undergoing regular abdominal imaging. Given the retrospective nature of our study, it is possible that some patients underwent surveillance investigations that were not captured, leading to a falsely low surveillance rate. But, given the extensive data collection sources that were reviewed, the chances of this are low unless patients had their investigations out of province, which did not appear to be the case. Also, for our study, compliance was defined as having the recommended screening test at least

\begin{tabular}{|c|c|c|c|c|c|}
\hline Specialty & $\begin{array}{l}\text { Seen } \\
\text { at } \\
\text { least } \\
\text { once }\end{array}$ & $\begin{array}{c}\text { Eye } \\
\text { exam } \\
\text { arranged } \\
\text { by }\end{array}$ & $\begin{array}{c}\text { CNS } \\
\text { imaging } \\
\text { arranged } \\
\text { by }\end{array}$ & $\begin{array}{l}\text { Abdominal } \\
\text { imaging } \\
\text { arranged } \\
\text { by }\end{array}$ & $\begin{array}{l}\text { Urine } \\
\text { screen } \\
\text { arranged } \\
\text { by }\end{array}$ \\
\hline Ophthamology & 84.2 & 10.5 & 6.3 & 12.5 & 0.0 \\
\hline Neurology & 15.8 & 0.0 & 0.0 & 0.0 & 0.0 \\
\hline Neurosurgery & 73.7 & 15.8 & 81.3 & 25.0 & 5.3 \\
\hline Urology & 42.1 & 0.0 & 0.0 & 12.5 & 0.0 \\
\hline Medical genetics & 89.5 & 31.6 & 0.0 & 25.0 & 10.5 \\
\hline $\begin{array}{l}\text { Internal medicine/ } \\
\text { pediatrics }\end{array}$ & 63.2 & 15.8 & 12.5 & 18.8 & 31.6 \\
\hline
\end{tabular}


Bradley et al.

$75 \%$ of the time, and thus one could point out that if the definition of compliance chosen was $100 \%$, the compliance rates would be even lower than those reported here.

Our study did not address why compliance with surveillance was low, which is a limitation. The 2 main possibilities are that patients did not follow through with the ordered investigations or that doctors did not arrange the appropriate investigations. We strongly suspect the latter given that the management of patients with VHL disease in NS appears to be largely uncoordinated and different aspects of care were delivered by many different specialists. Some aspects of care were not delivered by anyone. This may be the case in many areas of Canada. Recognition of these deficiencies offers an enormous potential for improvement.

von Hippel-Lindau disease is a complex disease requiring a multidisciplinary team of specialists including ophthalmology, neurosurgery, neurology, medical genetics, urology, internal medicine and pediatrics. It is also a disease that involves a pediatric population who need adequate transition and follow-up into the adult health care system. What our study points out is that current management of patients with $\mathrm{VHL}$ disease is haphazard and uncoordinated, resulting in poor surveillance of patients. Care must be coordinated by a designated team that helps arrange the surveillance and care of patients and their families with regular involvement of other multidisciplinary team members as needed. Currently this is not being done in NS but there is a great opportunity to develop such a model to the benefit of all.

From the *Division of Medical Oncology, Queen Elizabeth II Health Sciences Centre, Halifax, NS, the †Maritime Medical Genetics Service, IWK Health Centre, Halifax, NS, the $\neq$ Division of Medical Genetics, Department of Pediatrics, Queen Elizabeth II Health Sciences Centre, Halifax, NS

This article has been peer reviewed.

Competing interests: None declared.

\section{References}

1. Canadian cancer statistics 2008. Canadian Cancer Society, National Cancer Institute of Canada, Public Health Agency of Canada, Statistics Canada. Available: www.cancer.ca/Canada-wide/About\%20cancer/Cancer\%20statistics/ /media/CCS /Canada\%20wide/Files\%20List/English\%20files\%20heading/pdf\%20not\%20in \%20publications\%20section/Canadian\%20Cancer\%20Society\%20Statistics\%20PDF\%20 2008_614137951.ashx (accessed 2008 Dec 23).

2. Maher ER, Yates JR, Harries R, et al. Clinical features and natural history of von Hippel-Lindau disease. Q J Med 1990;77:1151-63.

3. Choyke PL, Glenn GM, Walther MM, et al. The natural history of renal lesions in von Hippe-Lindau disease: a serial CT study in 28 patients. AJR Am J Roentgenol 1992; 159:1229-34.

4. Hes FJ, Feldberg MAM. Von Hippel-lindau disease: strategies in early detection. Eur Radiol 1999;9:598-610.

5. Harries RW. A rational approach to radiological screening in von Hippe-Lindau disease. J Med Screen 1994; 1:88-95.

6. Lonser RR, Glenn GM, Walther M, et al. von Hippel-Lindau disease. Lancet 2003; 361:2059-67.

7. Green J. Protocol for von Hippe-Lindau disease patients. St. John's: Newfoundland VHL Care Group, Health Sciences Centre.

8. Chan-Smutko G. Gayun, Plon, et al. Surveillance protocols of VHL disease. Waltham (MA): UpToDate version 16.1; 2008.

9. VHL Family Alliance International 2001. VHL handbook, suggested protocol for screening. Available: www.vhl.org/handbook/vhlhb4.php (accessed 2009 Jan 12).

10. Grubb RL III, Choyke PL, Pinto PA, et al. Management of von Hippel-Lindauassociated kidney cancer. Nat Clin Pract Urol 2005;2:248-55.

11. Latif F, Tory K, Gnarra J, et al. Identification of the von Hippel-Lindau disease tumor suppressor gene. Science 1993;260:1317-20.

12. Kim WY, Kaelin WG. Role of VHL gene mutation in human cancer. J Clin Oncol 2004; 22:4991-5004

13. Yao M, Yoshida M, Kishida $T$, et al. VHL tumor suppressor gene alterations associated with good prognosis in sporadic clear cell carcinoma. J Natl Cancer Inst 2002;94:1569-75.

14. Linehan WM, Vasselli J, Srinivasan R, et al. Genetic basis of cancer of the kidney: disease-specific approaches to therapy. Clin Cancer Res 2004;10:6282s-9s.

15. Sims KB. von Hippel-Lindau disease: gene to bedside. Curr Opin Neurol 2001;14:695703.

16. Kaelin WG Jr. The von Hippe-Lindau tumor suppressor protein and clear cell renal carcinoma. Clin Cancer Res 2007;13:680s-4s.

17. Choyke PL, Glenn GM, Walther MM, et al. von Hippel-Lindau disease: genetic, clinical, and imaging features. Radiology 1995;194:629-42.

18. Goldfarb DA. Nephron sparing surgery and renal transplantation in patients with renal cell carcinoma and von Hippel-Lindau disease. J Intern Med 1998;243:563-7.

Correspondence: Dr. Lori Wood, Division of Medical Oncology, Queen Elizabeth II Health Sciences Centre, Rm. 471, Bethune Bldg, 1278 Tower Rd., Halifax NS B3H 2Y9; fax 902 473-6186; lori.wood@cdha.nshealth.ca 